\title{
EFFECT OF PROTECTED FAT ON PRODUCTIVE AND REPRODUCTIVE PERFORMANCE OF FRIESIAN LACTATING COWS DURING POSTPARTUM PERIOD
}

\author{
M. A. Abu El-Hamd ${ }^{1}$, N. Ewada ${ }^{2}$ and Noura B. A. Bayoumy ${ }^{2}$ \\ 1- Animal Production Research Institute, Agriculture Research Center, Dokki, Egypt, 2- Department \\ of Animal Production, Faculty of Agriculture, Kafr E-Sheikh University, Egypt
}

\section{SUMMARY}

The objective of this study was to evaluate the effects of adding protected fat (PF) in the ration of lactating cows on feed intake, digestibility coefficients and rumen activity as well as reproductive performance during the period from calving to six months of lactation. A total of 12 Friesian lactating cows between the $1^{\text {st }}$ and $2^{\text {nd }}$ parity and live body weight $(L B W)$ of $532.7 \pm 23.5 \mathrm{~kg}$ were used. Cows in the $1^{\text {st }}$ group were fed concentrate feed mixture $(C F M)$ as control $(G 1)$, while cows in the $2^{\text {nd }}$ group were fed CFM supplemented with 5\% protected fat $(G 2)$.

Average daily DM intake was nearly similar in G1 and G2. Average daily TDN intakes were higher in $G 2$ by about $4.7 \%$ than G1. Higher digestibility coefficient was observed in G2 than G1. pH of rumen liquor were higher $(P<0.001)$ in $G 2$ than in $G 1$ (6.06 vs. 5.83), while concentration of VFA's was not significant by treatment $(13.63$ and $14.15 \mathrm{mEq} / 100 \mathrm{ml})$. Concentration of $\mathrm{NH}_{3}-\mathrm{N}$ was higher $(P<0.0)$ in $G 1$ than $G 2$. Concentration of acetic acid in rumen liquor of cows of $G 2$ was higher $(P<0.001)$ in $G 2$ than $G 1$, while propunic acid showed a reverse trend $(P<0.05)$. No significant difference was observed between the two studied groups concerning concentration of butiric and isobutiric acids. Changes of LBW was higher ( $P<0.05)$ in $G 2$ than $G 1$ (7.73 vs. $14.5 \mathrm{~kg}$, respectively). Daily milk yield and fat corrected milk increased $(P<0.05)$ by about 10.34 and $21.99 \%$ in $G 2$ than $G 1$. Percentage of fat and protein in milk cows were higher $(P<0.05)$ in $G 2$ than $G 1$ and somatic cell count decreased $(P<0.05)$ by about $19.52 \%$ in G2 than G1. Number of ovulatory cycles / cow during the experimental period decreased $(P<0.05)$ in $G 2$ than $G 1$ Postpartum first estrous interval was not affected by treatment, while postpartum first service interval and service period length were shorter $(P<0.001)$ in $G 2$ than in G1. Cows in G2 showed shorter days open period $(108.8 d)$ than $G 1(150.5 d)$.

In conclusion feeding Friesian cows during the $1^{\text {st }}$ and $2^{\text {nd }}$ parities on CFM supplemented with 5\% protected fat improved milk yield and post partum reproductive traits.

Keywords: Friesian, protected fat, milk yield, postpartum, ovarian activity, reproductive performances

\section{INTRODUCTION}

Lactating dairy cattle expend more energy during peak milk production than what is consumed through their diets, creating a negative energy balance in the animal. Consuming an energy-dense diet is necessary in order to cover the nutrition requirements of high yielders dairy cows. Fat is added to the diet to increase energy density without decreasing fiber content. Concentrates are typically added to the diet as an energy source and substitute for forage content of the diet, which will decrease the fiber content of the diet, negatively affecting rumen bacteria (Andrew et al., 1991).

Excess fats added to the diet more than 5\% of dry matter intake would reduce digestion in the rumen. Long-chain fatty acids interact with microorganisms in the rumen, interfering with their digestive actions, and creating toxic effects in the rumen (Chalupa et al., 1986). Ruminants depend on lipids as an energy source in order to sustain high milk output while maintaining body weight during high production. Research conducted by Palmquist and Jenkins (1980) observed that cows fed diets comprised of $4-7 \%$ fat experienced a 2$10 \%$ increase in milk production when compared to those cows fed diets comprised of only $1-3 \%$ fat.

This study was planned to investigate the effect of feeding protected fat diets on digestibility, rumen parameters, milk production and reproductive performance during early lactation of Friesian cows.

\section{MATERIALS AND METHODS}

The present study was carried out at Animal Production Department, Faculty of Agriculture, Kefr El-Sheikh University in cooperation with Sakha Animal Production Research Station, belonging to the Animal Production Research Institute, Agricultural Research Center, Ministry of Agriculture, Egypt. 
Experimental Animals:

A total of 12 Friesian cows were used in this study. Cows average live body weight of $532.7 \pm 23.5 \mathrm{~kg}$ aged ranging between 2-4 years and were at $1^{\text {st }}$ and $2^{\text {nd }}$ parity. The experimental period extended from calving to six months of lactation. Cows were assigned into two groups according to live body weight (LBW), parity and age. Cows in the $1^{\text {st }}$ group (G1) were fed on concentrate feed mixture (CFM) as control, while, cows in the $2^{\text {nd }}$ group $(\mathrm{G} 2)$ were fed on CFM supplemented with $5 \%$ protected fat (Magnapac, Ca-soap of fatty acids). Cows were free of any diseases with healthy appearance and they were housed in groups and were kept in yards semi-shaded.

\section{Feeding system and management:}

Concentrate feed mixture (CFM) used in feeding cows was composed of $37.5 \%$ yellow corn, $20 \%$ soybean meal, $15 \%$ corn gluten, $22.5 \%$ wheat bran, $3 \%$ molasses, $0.5 \%$ premix and $1.5 \%$ common salt. Chemical composition of different feedstuffs used in formulation of the experimental rations is presented in Table (1).

Cows of G1 and G2 fed equal amounts of $\mathrm{CFM}$, rice straw (RS), fresh berseem $(\mathrm{BH})$ and corn silage (CS) (APRI, 2002) based on LBW, milk yield and fat percentage, which was about $10.5 \mathrm{~kg}$ DM containing $16 \% \mathrm{CP}$ on DM basis. The daily allowances were adjusted every 15 days according to LBW, milk yield and fat milk percentage. The animals were fed twice daily at 8:00 a.m. and 2:00 p.m., while fresh water was made available all daytime. The Magnapac (NOREISA, Madrid, Spain) supplemented to the diet as protected fat contained $84 \%$ palm oil (44\% palmitic, $40 \%$ oleic, $9.5 \%$ linoleic, $5 \%$ stearic and $1.5 \%$ myrstic acid), $12.5 \%$ Ca-carbonate and $3.5 \%$ moisture). Representative monthly samples of foodstuffs were analyzed according to the official methods of the A.O.A.C. (1995).

\section{Experimental Procedure:}

Throughout the feeding period, changes in live body weight were monthly recorded for each cow. Three digestibility trials were conducted using three cows chosen randomly from each group during the $3^{\text {rd }}$ month of lactation period. Cows were individually kept during the collection period and feces were collected from the rectum daily in the morning before feeding and at evening after milking for seven days. At the end of the collection period, representative samples (10\% of fresh feces) were taken from each cow and dried at $60^{\circ} \mathrm{C}$ for 48 hours. After drying samples were grinded to pass through a $0.5 \mathrm{~mm}$ screen and kept in tight-plastic containers for chemical analysis.
Digestion coefficients of various nutrients of the experimental rations were determined using insoluble ash method based on the use of silica as a marker (Van Kulin and Young, 1977). Nutritive values as TDN and DCP of different experimental rations were calculated according to the obtained digestibility coefficients. Representative samples from CFM, CS, RS, BH and faces were also taken and prepared for the chemical analysis (A.O.A.C., 1995).

\section{Rumen Liquor Aand Blood Sampling:}

Three cows were randomly chosen from each group for rumen liquor collection $(200 \mathrm{ml})$ using stomch tube at the $2^{\text {nd }}, 3^{\text {rd }}, 4^{\text {th }}$ and $5^{\text {th }}$ months of post partum, four hours post feeding. The ruminal fluid was strained through four layers of cheesecloth and $\mathrm{pH}$ values were immediately recorded by digital $\mathrm{pH}$-meter (Model HI 8424). Two $\mathrm{ml}$ toluene and $2 \mathrm{ml}$ paraffin oil were added to each rumen liquor sample of each animal and then stored at $-20^{\circ} \mathrm{C}$ until determination of concentration of $\mathrm{NH}_{3}-\mathrm{N}$ and volatile fatty acids $/ 100 \mathrm{ml}$ rumen liquor. Ammonia-nitrogen $\left(\mathrm{NH}_{3}-\right.$ $\mathrm{N})$ concentration was determined according to micro diffusion method (Conway, 1978), while concentration of total volatile fatty acids (VFA's) was determined by distillation according to Eadie et al. (1967). Individual volatile fatty acids were determined by liquidgas chromatography (Intersmat, IGC 120 FBI).

Blood samples were collected from jugular vein from all experimental cows at 3 - 4 dayinterval throughout an experimental period. Blood samples were centrifuged at $3000 \mathrm{rpm}$ for 10 minutes to separate blood plasma which stored at $-200 \mathrm{C}$ until analysis. Direct radioimmunoassay technique was performed for determination of plasma progesterone concentration using antibody-coated tubes kit (Diagnosis systems, laboratories Texas, USA) according to the procedure outlined by the manufacture. The standard curve of progesterone concentration ranged from 0 to 2.4 and 0 to $3.6 \mathrm{ng} / \mathrm{ml}$. The intra-and inter assay coefficient of variation were 5.4 and $9.1 \%$, respectively.

\section{Detection Of Estrus And Insemination:}

10 days postpartum experimental cows of G1 and G2 were exposed to an infertile bull to detect estrous cases. Teasing rounds (20 minutes) were conducted three times daily at 6 , 12 and $15 \mathrm{~h}$ to recognize the onset of the $1^{\text {st }}$ estrus. Estrus was identified when cows showed complete receptivity to the teaser and stood quietly to be mounted. Cows those be recognized to be on heat were artificially inseminated. Number and length of estrous cycles from calving up to conception were recorded. Postpartum $1^{\text {st }}$ ovulation (PPOI), $1^{\text {st }}$ 
estrus (PPEI) and $1^{\text {st }}$ service (PPSI) intervals, number of services per conception (NSC), service period length (SPL), days open (DO) and conception rate (CR\%) were calculated. Conception rate was calculated as the proportion of conceived cows relative to inseminated cows multipliable by 100 . Pregnancy was diagnose by rectal palpation after day 60 post-insemination.

\section{Statistical Analysis:}

Data obtained in this study were statistically analyzed according to T-test models procedure adopted by SPSS (1997).

\section{RESULTS AND DISCUSSION}

\section{Feed Intake:}

Results in Table (2) show the average of daily dry matter intake (DMI), total digestible nutrients (TDN) and digestible crude protein (DCP) intakes from the experimental rations during the feeding period. Animals were fed in group and not individually, therefore, it was not possible to test the significance of differences in feed intake among the experimental groups of animals. During the postpartum period, average daily TDN of intake was higher $(\mathrm{P}<0.05)$ in $\mathrm{G} 2$ than in $\mathrm{G} 1$, while average daily intake of DM and CP were nearly similar fin both groups (Table 2). Similar results were obtained by Jenkins (2000) in lactation Jersy cows, who found DMI did not affect by protected fat.

The increase in TDN intakes of G2 was probably due to the addition of protected fat, The R:C ration in these experimental diets lies between 58:42 on average and it could be considered suitable range for dairy cattle. Generally, the average DM, TDN and CP intakes $(\mathrm{kg} / \mathrm{d} / \mathrm{h})$ during postpartum periods were higher than the recommended values of cows according to APRI (2002) (Table 2).

\section{Digestibility coefficients and feeding values:}

Crude protein and ether extract digestion were higher $(\mathrm{P}<0.05)$ in $\mathrm{G} 2$ than in G1 (Table $3)$. On the other hand, digestibility coefficients of DM, OM, CF and Nitrogen free extract (NFE) were not affected by supplementing CFM with protected fat $(5 \%)$

Voigt et al. (2006) reported that digestibility of organic matter was higher for diet with Ca-PFA than for diets with hydrogenated triacylglyceride from palm oil and fractionated triacylglyceride from palm oil, because of increased digestibility of ether extract. Supplemental fat is increasingly included in the diets Abd El-Hafeez et al. (2002) in cows low product yield. This allows to modify the fatty acids pattern of the milk fat (Precht et al., 2001) and to improve the energy supply of the cow. Furthermore, supplemental fat act as nutritional modifier of physiology and metabolism (Voigt et al., 2005). However, unprotected, unsaturated fatty acids can be toxic to the rumen microbes unless saturated by microbial hydrogenation (Harfoot, 1981).

Regarding the effect of protected fat on nutritive values of the tested rations (Table 3), it was clear that the total digestible nutrients (TDN \%) was higher $(\mathrm{P}<0.05)$ in $\mathrm{G} 2$ than in G1. On the other hand, DCP value was not significantly affected by dietary supplementation. The improvement in the feeding values as (TDN) was 4.09 for G2 compared with G1. Generally, the improvement of feeding values in protected fat was attributed of higher digestibility coefficients in G2 than in G1.

\section{Rumen Parameters:}

Rumen $\mathrm{pH}$ of Friesian cows was affected significantly by dietary treatment $(\mathrm{P}<0.001)$. The $\mathrm{pH}$ value was higher $(\mathrm{P}<0.001)$ in cows of G2 than of G1 (Table 4). Differences in rumen $\mathrm{pH}$ is affected by production rate of VFA's via fermentation process of carbohydrates (Ahmed, 1996). It is also affected by feeding time and type (Omer, 1999). In accordance with the present results of $\mathrm{pH}$ of rumen liquor in G2, Chalupa et al. (1986) and Onetti et al. (2001) reported that $\mathrm{pH}$ of the rumen liquor is not affected by feeding protected fat.

The VFA,s concentration was not affect by dietary treatment. Overall mean of VFA's concentration was nearly in cows of G1 and G2 (Table 4). The insignificant differences in concentration of VFA's as affected by PF diet come in line with the results of Omer (1999) and Onetti et al. ( 2001). Pattern of VFA's concentrations showed reversible trends to those of $\mathrm{pH}$ values (Table 4) in rumen liquor of each group, there are agreement with results obtained by Abu El-Hamd (2003).

The concentration of NH3-N (mg/100 ml) in rumen liquor tended to be lower $(\mathrm{P}<0.05)$ in G2 than G1 (Table 4). Present results are in agreement with, Onetti et al. (2001); Demeterova et al. (2002) and Abu El-Hamd (2003), who found a significant reduction in $\mathrm{NH}_{3}-\mathrm{N}$ concentration in rumen liquor of cows fed protected fat compared with the control group. On the other hand, Omar (1994) reported no effect of protected fat on rumen concentration of NH3-N.

The concentration of acetic acid in rumen liquor was higher $(\mathrm{P}<0.001)$ in $\mathrm{G} 2$ than $\mathrm{G} 1$, whereas, propunic acid was lower $(\mathrm{P}<0.05)$ in G2 than in G1. The concentration of butyric acid and isobutyric acid in rumen liquor showed no significant difference in G1 and G2 (Table 4). 
In contrast, Chalupa et al. (1986) observed that adding $10 \% \mathrm{Ca}$-vegetable fat to rations of lactating cows decreased acetate concentration and acetate to propionate ratio, while increased propionate concentrations cows fed fat supplemented ration compared to control. Meanwhile, Kim et al. (1993) reported no effect of feeding ration containing protected fat on concentrations of acetate and propionate, and acetate to propionate ratio.

\section{Body Weight Changes:}

Change of LBW was higher $(\mathrm{P}<0.05)$ in $\mathrm{G} 2$ than in G1 (Table 5). The results in this study are similar to that obtained by El-Diahy (2004) in lactating Friesian cows when fed protected fat and supplemental oil.

\section{Milk Yield:}

Average daily milk yield (ADMY) was not affected by treatment, but, $4 \%$ fat corrected milk yield $(\mathrm{FCMY})$ were higher $(\mathrm{P}<0.05)$ by 10.34 and $21.99 \%$ for G2 than G1 (Table 6). It is of interest to note that ADMY peak was affected by dietary treatment, whereas lactation peak was during the $3^{\text {rd }}$ month of lactation in G1, while it was during the $2^{\text {nd }}$ month of lactation In G2 (Figure 1). Average of monthly milk yield (AMMY) or $4 \%$ fat corrected monthly milk yield (FCMY) of cows in G2 higher $(\mathrm{P}<0.05)$ by 12.92 and $25.06 \%$ than G1(Table 6). The improvement in the milk yield in G2 may be due to the increase of net energy intake.

The same trend was also reported by Schneider et al. (1988) and Garbswortuy (1996) who indicated that adding Ca-salts of fatty acids to Holstein cow's rations increased milk yield. El-Diahy (2004) found that supplementing diets of lactating Friesian cows with protected fat or supplemental oil, increased significantly ADMY and FCMY than control. Results of other studies indicated that a positive effect of diet supplementation with calcium salts of fatty acids on enabled to increase daily milk yield by $3.02 \mathrm{~kg}$ (34.77 vs. $31.75 \mathrm{~kg}$ ), and levels of fat (by 0.41 percentage unit), especially at the peak of lactation (Schroeder et al., 2004).

Percentage of fat and protein in milk cows were higher $(\mathrm{P}<0.05)$ in $\mathrm{G} 2$ than that in $\mathrm{G} 1$. However, percentages of lactose total solid and solid not fats were not affected by treatment (Table 6).

The SCC was lower $(\mathrm{P}<0.01)$ by about $19.52 \%$ for cows of G2 than G1 (Table 6). These results are similar to those obtained by Strusińska et al. (2006), who reported that somatic cell count decreased during the first 120 days of lactation by Megapro Plus ${ }^{\circledR}$ supplementation to diet.
Ovarian Activity:

$\mathrm{G} 2$ had lower $(\mathrm{P}<0.05)$ average number of ovulatory cycles compared with G1. On the other hand, no statistical differences were observed between the two studied groups in average number of total ovulations or ovulatory cycle length during the experimental period (Table 7). Average progesterone and concentration of progesterone at peak during the ovulatory cycles in $\mathrm{G} 2$ increased $(\mathrm{P}<0.05)$ compared to G1. Moreover, progesterone decreased $(\mathrm{P}<0.05)$ prior to estrus incidence in G2 compared to G1. However, interval to progesterone peak during the ovulatory cycles was not significantly affected (Table 7).

\section{Reproductive Performance:}

Postpartum estrus interval (PFEI) of cows was no affected by treatment (Table 8). Obtained PFEI is in agreement with those reported by El-Diahy (2004), who reported that the PFEI ranged between 33 to 42 days in cows fed protected fat. Although, Lu et al. (1992) indicated that the length of PFEI showed wide variation in Holstein cows (28.3 and 69.0 days), which may be due to the variation in frequency and regime of estrous detection. However, Wafa (2004) found that PPEI was altered in cows fed dry fat than those fed control diet.

The present results showed that $\mathrm{G} 2$ showed shorter post partum service interval $(\mathrm{P}<0.001)$, service period $(\mathrm{P}<0.01)$ and days open $(\mathrm{P}<0.001)$, as well as less $(\mathrm{P}<0.01)$ number of services per conception and higher $(\mathrm{P}<0.05)$ conception rate compared to G1 (Table 8).

El-Diahy (2004) reported close results to the present one. He reported service period length of 33 days for cows fed protected fat. Moreover, low number of services /conception agrees with that result of Wafa (2004).

Obtained higher conception rate in G2 comes in agreement with the findings of Schneider et al. (1988) and Wafa (2004) who reported that Holstein cow fed diets supplemented with $\mathrm{Ca}$ salts of fatty acids were had conception rate than control one.. Dairy cows fed fat supplementation showed shorter interval to first service, higher conception rate as reported by Armstrong et al. (1990) and Carroll et al. (1994).

In conclusion feeding Friesian cows during the $1^{\text {st }}$ and $2^{\text {nd }}$ parities on CFM supplemented with $5 \%$ protected fat improved milk yield and post partum reproductive traits.

\section{REFERENCES}

A.O.A.C., 1995. Official Methods of Analysis 15th ed. Association of Official Analytical Chemists. Arlington, Virginia, USA. 
Abd El-Hafeez, H., S. Tawfik, M.A. Kandeil and A.N. Sazed, 2002. The effect of protected fat on milk yield and composition, Digestibility, and some biochemical parameters in low Producing cows. J. Assiut, Veterinary Medicin, 46 (.92):84-104.

Abu El-Hamd, M. A., 2003. Rumenal development in suckling calves fed protected fat and protected protein. Ph.D. Thesis, Faculty of Agriculture, Mansoura University, Egypt.

Ahmed, S.K.S., 1996. The use of different energy and nitrogen sources in complete rations. M. Sc. Thesis, Faculty of Agriculture, Ain Shams University, Cairo Egypt.

Andrew, S.M., H.F. Tyrrell, C.K. Reynolds, and R.A. Erdman, 1991. Net energy for lactation of calcium salts of long-chain fatty acids for cows fed silage-based diets. J. Dairy Sci.; 74:2588-2600.

Animal Production Research Institute, 2002. Animal Nutrition Scientifically and Practically. $2^{\text {nd }}$ Ed. Animal Production Research Institute, Agricultural Research Center, Ministry of Ag-riculture, Dokki, Giza, Egypt.

Armstrong, J.D., E.A. Goodall, F.J. Gordon, D.A. Rice, and W.J. McCaughey, 1990. The effects of levels of concentrate offered and inclusion of maize gluten or fish meal in the concentrate on reproductive performance and blood parameters of dairy cows. Anim. Prod. 50:1.

Carroll, D.J., F.R. Hossain, and M.R. Keller, 1994. Effect of supplemental fish meal on the lactation and reproductive performance of dairy cows. J. Dairy Sci.; 77:3058.

Chalupa, W.; B. Veccbiarelli; A.E. Elaer; D.S. Kronfeld; D. Sklan and D.L. Palmquist, 1986. Ruminal fermentation. In-vitro as influenced by long-chain fatty acids. J. Dairy Sci. 69:1293.

Conway, E. J., 1978. Microdiffusion analysis and volumetric error. 4th Ed. The McMillian Co., N.Y.

Demeterova. M., V. Vajda, P. Pastierik and A. Koteles, 2002. The effect of protected fat and protein supplements on rumen metabolism, on some parameters of intermediary metabolism, and on the quality and production of milk in dairy cows. Folia. Veterinaria. 46: 1, 20.

Eadie, J.M., P.N. Hobson and S.O. Mann, 1967. A note of some comparisons between the rumen content of barley fed steers and that of young calves also fed on high concentrate rations. J. Anim. Prod., 9: 247.
El-diahy Y.M., 2004. Effect of fat supplementation on productive and reproductive performance in lactating Friesian cows. M. Sci. Thesis, Faculty of Agriculture, Tanta University, Egypt.

Garbswortuy, P.C., 1996. The effects of milk yield and composition of incorporating lactose into the diet of dairy cows given protected fat .J. Anim Sci., 62:1.

Harfoot, C.G., 1981. Lipid metabolism in the rumen. In: Lipid metabolism in ruminant animals, Ed. Christie et al., Pergamon Press, Ooxford, UK, 1981, p. 21-55.

Jenkins, T.C., 2000. Feeding oliamide to lactating Jersey cows. 1- Effects of lactation performance and milk fatty acid composition. J. Dairy Sci., 83:332.

Joźwik A., Śliwa- Joźwik A., Strzałkowska N., Krzyżewski J., Kołątaj A. (2004): Zależność między liczbą komorek somatycznych apoziomem GSH, wydajnością i składem chemicznym mleka. Med. Weter, 60, 1215-1217.

Kim, Y.K., D.J. Schingoethe; D.P. Casper and F.C. Ludens, 1993. Supplemental dietary fat from extruded soybeans and calcium soaps of fatty acids for lactating cows. J. Dairy Sci. 76: 197.

Lu, G., S. Y. Hwang, S.P. Yang, G.M. Chang and T.T. Hsu, 1992. Studies on housing of lactating Holstein cows after calving in air conditioned baens during the hot season in Taiwan. J. Taiwan. Live. Stock. Rep. 25:1.

Omer, F. M., 1994. Performance of fattening lambs on non-conventional rations containing different levels of fats. M. Sc. Thesis, Faculty of Agriculture, Ain Shams University, Cairo Egypt.

Omer, F.M., 1999. Using protected fat prepared from soap industry by-products in finishing rations of Friesian bulls. Ph. D. Thesis, Faculty of Agriculture, Ain Shams University, Cairo Egypt.

Onetti, S.G., R.D. Shaver, M.A. McGuire and R.R. Grummer, 2001. Effect of type and level of dietary fat on rumen fermentation and performance of dairy cows fed corn silage-based diets. J. Dairy Sci.; 84: 2751.

Palmquist D. L., and T. C. Jenkins. 1980. Fat in lactation rations: review. J. Dairy Sci. 63:1.

Precht, D., J. Voigt, H. Hagemeister, and W. Kanitz, 2001. The influence of dietary rumen-protected linoleic acid on milk fat composition, spreadability of butter and energy balance in dairy cows. Eur. J. Lipid Sci. Technol. 103, 2001, p. 783-792.

Schneider, P., D. Sklan, W. Chalupa and D.S. Kronfeld, 1988. Feeding calcium salts of fatty acids to lactating cows. J. Dairy Sci.; $71: 2143$. 
Schroeder G.F., G.A. Gagliostro, F. Bargo, J.E. Delahoy, and L.D. Muller, 2004. Effects of fat supplementation on milk production and composition by dairy cows on pasture: A review. Livest. Prod. Sci.; 86, 1-18.

SPSS for Windows, 1997. Statistical package for the social science, Release 6, SPSS, Inc. Chcago, USA

Strusińska, D.,D. Minakowski, B. Pysera and J. Kaliniewicz, 2006. Effects of fat-protein supplementation of diets for cows in early lactation on milk yield and composition. Czech J. Anim. Sci., 51, 2006 (5):196-204.

Van Kulin, J. and B.A. Young, 1977. Evaluation of acid-isoluble ash as a natural marker in ruminant digestion studies. J. Anim. Sci.; 44: 282.
Voigt, J., K. Gaafar, W. Kanitz, D. Precht, F Becker, F. Schneider, M. Spitschak, U. Schönhusen, P. Junghans, J. Aschenbach and G. Gäbel, 2005. Verwertung von Glucose und langkettigen Fettsäuren durch die laktierende Milchkuh bei Fütterung einer fettangereicherten Diät. In: Deutsch. Tierärztl. Wochenschr. 112, 2005, p. 423425.

Voigt, J; S. Kuhla; K. Gaafar; M. Derno and H. Hagemeister, 2006. digestibility of rumen protected fat in cattle. Slovak J. Anim. Sci.; 39 (1-2): $16-19$.

Wafa, W.M., 2004. Improving the fertility in Friesian cattle. M. Sci. Thesis, Faculty of Agriculture Mansoura University, Egypt

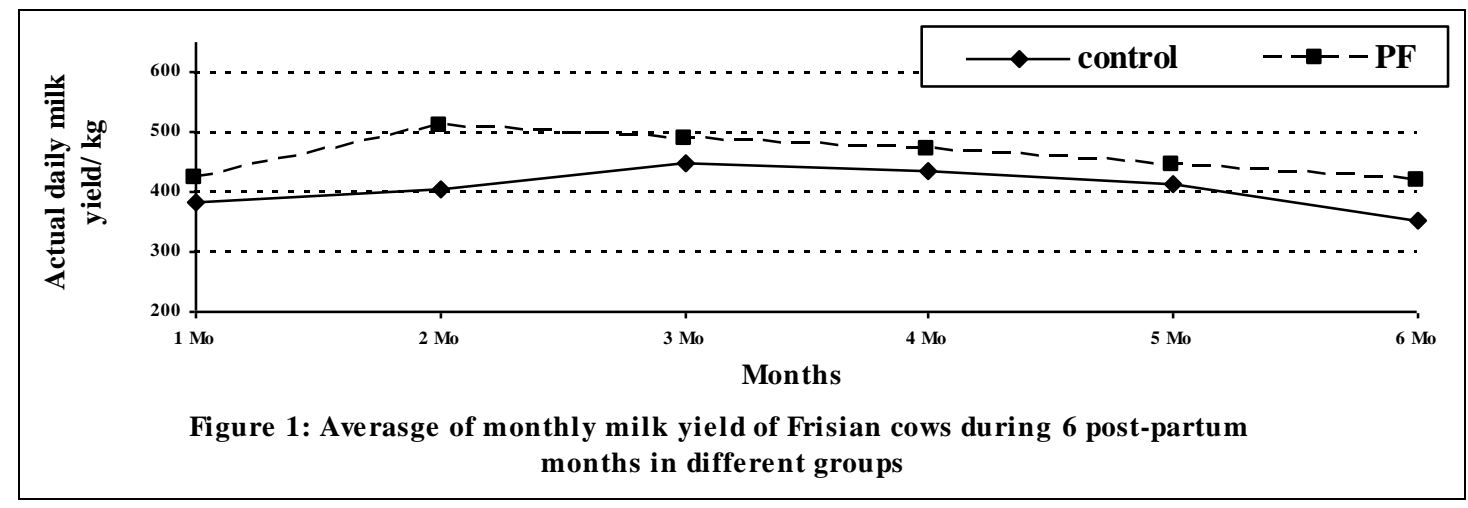

Table 1. Chemical analysis of different feedstuffs (on DM basis, \%) used in feeding cows in experimental groups

\begin{tabular}{lcccc}
\hline \multicolumn{1}{c}{ Item } & \multicolumn{4}{c}{ Chemical composition (\%) } \\
& CFM & Rice straw & Berseem hay & Corn silage \\
\hline Dry matter, DM & 90.12 & 88.74 & 88.52 & 36.14 \\
Organic matter, OM & 89.24 & 80.83 & 88.78 & 90.4 \\
Crude protein, CP & 15.34 & 1.61 & 14.57 & 15.5 \\
Crude fiber, CF & 11.46 & 37.36 & 24.62 & 2.1 \\
Ether extract, EE & 5.02 & 1.51 & 6.12 & 16.0 \\
Nitrogen free extract & 57.42 & 40.35 & 43.47 & 56.8 \\
Ash & 10.76 & 19.17 & 11.22 & 9.6 \\
\hline
\end{tabular}

Table 2. Effect of feeding concentrate feed mixture (G1) and concentrate feed mixture supplemented with $5 \%$ protected fat (G2) on average daily DM intake (kg/head/day)

\begin{tabular}{lccccc} 
& \multirow{2}{*}{ Item } & \multicolumn{5}{c}{ Experimental rations (kg/day) } \\
\cline { 2 - 6 } & G1 & G2 & SE & Significance \\
\hline Concentrate feed mixture & 8.0 & 7.6 & - & - \\
Berseem hay & 4.2 & 4.1 & - & - \\
Rice straw & 3.1 & 3.2 & - & - \\
Corn silage & 15.4 & 15.7 & - & - \\
Protected fat & - & 0.40 & - & - \\
& & 19.25 & 19.35 & 1.24 & NS \\
& Total DMI & 11.67 & 12.22 & 0.12 & $*$ \\
\multicolumn{1}{c}{ Digestible crude protein (DCP) } & 1.66 & 1.67 & 0.01 & NS \\
\hline
\end{tabular}

NS: Not significant and * significant at $(\mathrm{P} \geq 0.05)$ 
Table 3. Effect $(\mathrm{X} \pm \mathrm{SE})$ of feeding concentrate feed mixture (G1) and concentrate feed mixture supplemented with $5 \%$ protected fat (G2) on digestion coefficient (\%).

\begin{tabular}{|c|c|c|c|c|}
\hline \multirow{2}{*}{ Item } & \multicolumn{2}{|c|}{ Treatments } & \multirow[b]{2}{*}{ SE } & \multirow{2}{*}{ Significance } \\
\hline & G1 & G2 & & \\
\hline DM & 65.73 & 65.96 & 0.71 & NS \\
\hline $\mathrm{OM}$ & 64.17 & 65.40 & 1.02 & NS \\
\hline $\mathrm{CP}$ & $74.44^{\mathrm{b}}$ & $77.11^{\mathrm{a}}$ & 0.55 & $*$ \\
\hline $\mathrm{CF}$ & 59.22 & 64.29 & 3.03 & NS \\
\hline $\mathrm{EE}$ & $71.56^{\mathrm{b}}$ & $78.93^{\mathrm{a}}$ & 1.9 & $*$ \\
\hline Nitrogen free extract & 63.44 & 61.89 & 1.14 & NS \\
\hline Ash & 77.20 & 72.79 & 2.62 & NS \\
\hline \multicolumn{5}{|l|}{ Nutritive values } \\
\hline TDN & $60.60^{\mathrm{b}}$ & $63.08^{\mathrm{a}}$ & 0.67 & $*$ \\
\hline DCP & 8.62 & 8.64 & 0.09 & NS \\
\hline
\end{tabular}

NS: Not significant and * significant at $(\mathrm{P} \geq 0.05)$.

Table 4. Effect $(\mathrm{X} \pm \mathrm{SE}$ ) of feeding concentrate feed mixture (G1) and concentrate feed mixture supplemented with $5 \%$ protected fat $(\mathrm{G} 2)$ on rumen parameters and fermentation of VFA in rumen liquor

\begin{tabular}{lcccc}
\hline \multirow{2}{*}{ Item } & \multicolumn{3}{c}{ Dietary group } & Significance \\
\cline { 2 - 5 } & G1 & G2 & SE & $*$ \\
pH values & 5.83 & 6.06 & 0.03 & NS \\
VFA's & 14.15 & 13.63 & 0.22 & $*$ \\
NH3-N (mg/100 $\mathbf{~ m l ) ~}$ & 22.2 & 20.56 & 0.34 & $* *$ \\
Fermentation of VFA & & & & $*$ \\
Acetic acid & 41.24 & 44.42 & 0.60 & $\mathrm{NS}$ \\
Propunic acid & 31.02 & 28.05 & 0.72 & $\mathrm{NS}$ \\
Butyric acid & 22.65 & 22.97 & 1.02 &
\end{tabular}

Table 5. Effect $(X \pm S E)$ of feeding concentrate feed mixture (G1) and concentrate feed mixture supplemented with $5 \%$ protected fat (G2) on live body weight (kg) and the LBW changes

\begin{tabular}{lcccc}
\hline \multirow{2}{*}{ Postpartum month } & \multicolumn{3}{c}{ Treatments } \\
\cline { 2 - 5 } & G1 & G2 & SE & Significance \\
\hline Live body weight & 517.5 & 506.67 & 10.2 & NS \\
Final live body weight & 521.40 & 514.40 & 11.4 & NS \\
Changes of LBW $(\mathrm{kg})$ & 3.90 & 7.73 & 1.2 & $*$ \\
\hline
\end{tabular}

NS: not significant and * significant at $(\mathrm{P} \geq 0.05)$

Table 6. Effect $(\mathrm{X} \pm \mathrm{SE})$ of feeding concentrate feed mixture (G1) and concentrate feed mixture supplemented with $5 \%$ protected fat (G2) on milk yield and milk compassion of Frisian cows during six months post-partum

\begin{tabular}{|c|c|c|c|c|}
\hline \multirow{2}{*}{ Months } & \multicolumn{2}{|c|}{ Dietary groups } & \multirow{2}{*}{ SE } & \multirow{2}{*}{ Significance } \\
\hline & G1 & G2 & & \\
\hline \multicolumn{5}{|l|}{ Milk yield } \\
\hline Actual milk yield (kg/day) & 13.54 & 14.94 & 0.81 & NS \\
\hline Fat $4 \%$ corrected milk yield (kg): & 11.96 & 14.59 & 0.76 & $*$ \\
\hline Monthly milk yield (kg): & 406.3 & 458.8 & 13.4 & $* *$ \\
\hline Monthly Fat corrected milk yield (kg): & 358.0 & 447.8 & 22.6 & $* * *$ \\
\hline \multicolumn{5}{|l|}{ Milk compassion $(\%)$ : } \\
\hline Fat & 3.21 & 3.85 & 0.09 & $* *$ \\
\hline Protein & 2.33 & 2.51 & 0.06 & * \\
\hline Lactose & 3.99 & 3.97 & 0.07 & NS \\
\hline Total solids & 11.10 & 11.25 & 0.25 & NS \\
\hline Solids not fat & 7.07 & 7.11 & 0.21 & NS \\
\hline Somatic cell count & 381.69 & 307.19 & 24.2 & $* *$ \\
\hline
\end{tabular}


Table 7. Effect $(\mathrm{X} \pm \mathrm{SE})$ of feeding concentrate feed mixture (G1) and concentrate feed mixture supplemented with $5 \%$ protected fat (G2) on postpartum ovarian activity of cows

\begin{tabular}{|c|c|c|c|c|}
\hline \multirow{2}{*}{ Item } & \multicolumn{2}{|c|}{ Dietary groups } & \multirow{2}{*}{ SE } & \multirow{2}{*}{ Significance } \\
\hline & G1 & G2 & & \\
\hline Number of ovulatory cycles/cow & 4.5 & 2.75 & 0.24 & $* *$ \\
\hline Number of ovulations /cow & 5.00 & 3.25 & 0.43 & NS \\
\hline Ovulatory cycle length (day) & 20.94 & 21.36 & 3.61 & NS \\
\hline Average of progesterone prior to estrus activity ${ }^{1}$ & 0.496 & 0.295 & 0.06 & $* *$ \\
\hline Average progesterone concentration $(\mathrm{ng} / \mathrm{ml})^{2}$ & 2.821 & 3.841 & 0.19 & NS \\
\hline Progesterone peak $(\mathrm{ng} / \mathrm{ml})^{2}$ & 6.090 & 7.221 & 0.56 & NS \\
\hline Interval to progesterone peak (day) ${ }^{3}$ & 11.56 & 10.73 & 1.53 & NS \\
\hline
\end{tabular}

1 From time of treatment to estrus incidence, 2 During ovulatory cycles and 3 from the beginning the ovulatory cycle NS: not significant and ${ }^{* *}$ significantly at $(\mathrm{P} \geq 0.01)$.

Table 8. Effect $(X \pm S E)$ of feeding concentrate feed mixture (G1) and concentrate feed mixture supplemented with $5 \%$ protected fat (G2) on postpartum reproductive performance

\begin{tabular}{lccc}
\hline \multirow{2}{*}{ Item } & \multicolumn{3}{c}{ Dietary group } \\
\cline { 2 - 4 } & G1 & G2 & Significance \\
\hline Postpartum first estrus interval & $41.60 \pm 2.37$ & $35.20 \pm 2.3$ & NS \\
Postpartum first service interval & $104.7 \pm 3.4$ & $82.5 \pm 2.6$ & $* * *$ \\
Service period length & $45.8 \pm 4.5$ & $26.3 \pm 4.8$ & $* *$ \\
Number of services / Conception & $2.75 \pm 0.365$ & $1.60 \pm 0.298$ & $* *$ \\
Days open & $150.5 \pm 14.86$ & $108.8 \pm 12.14$ & $* *$ \\
Conception rate & 66.67 & 83.34 & $*$ \\
\hline
\end{tabular}

NS: not significant, * significantly at $(\mathrm{P} \geq 0.05),{ }^{* *}$ significantly at $(\mathrm{P} \geq 0.01)$ and $* * *$ significantly at $(\mathrm{P} \geq 0.001)$.

$$
\begin{aligned}
& \text { أثر إضافة الدهن المحمى علي الكفاءة الإتتاجية والتناسلية للأبقار الفريزيان خلال فترة ما بعد الولادة } \\
& \text { محد عوض أبو الحمد 1و نبيل محد عويضة 2ونورا أبو المكارم بيومي2 } \\
& \text { 1- معهُ بحوثِ الإتتاج الحيواني، مركز البحوث الزراعية، وزارة الزرراعة، مصر، 2ـ قسم الإتتاج الحيواني، كليّة الزراعة، جامعة } \\
& \text { كفر الثنيخ, مصرِ }
\end{aligned}
$$

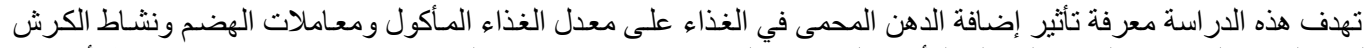

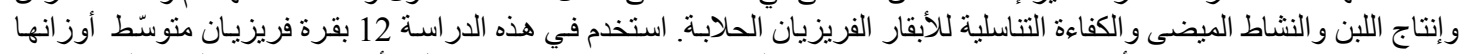

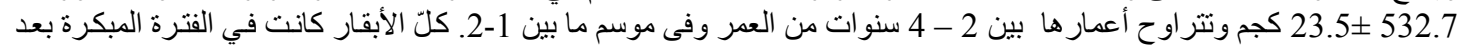

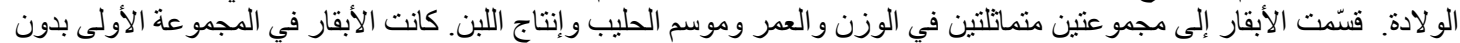



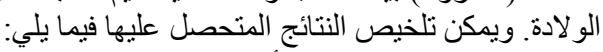

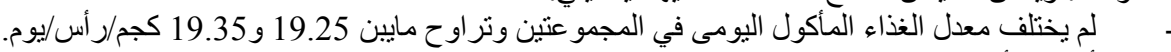

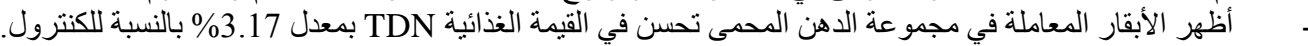



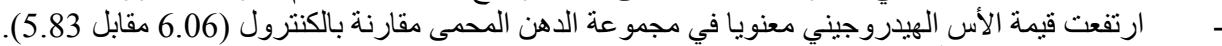

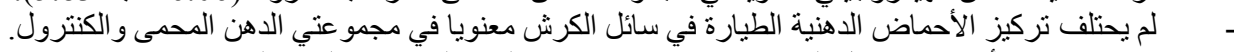



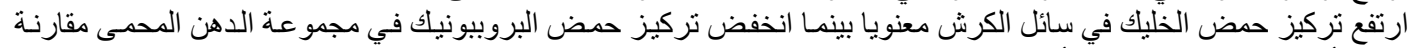

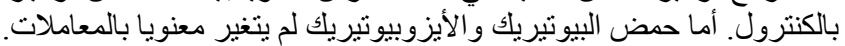

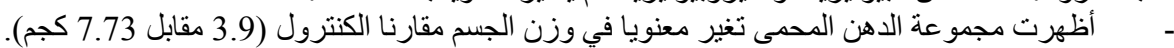

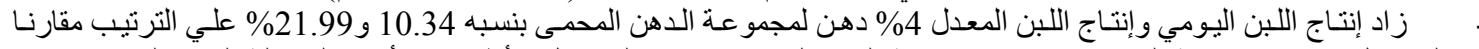

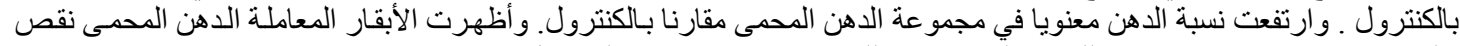

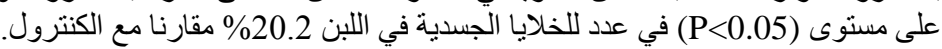

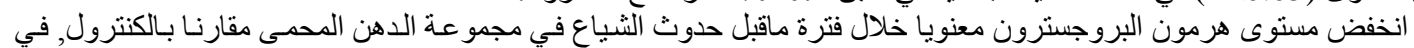



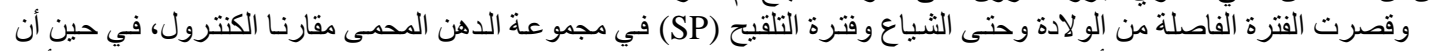

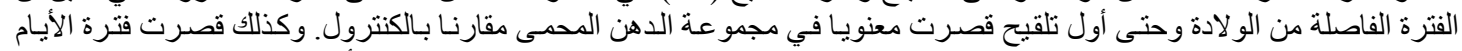

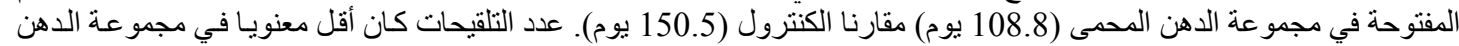

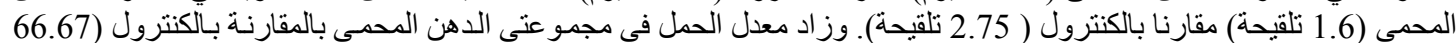

